\title{
Mechanism of Certain Abnormalities of the Circulation to the Limbs in Thyrotoxicosis*
}

\author{
Hermes A. Kontos, $\dagger$ William Shapiro, H. Page Mauck, Jr., David W. \\ Richardson, $\ddagger$ John L. Patterson, Jr., $\S$ and Alton R. Sharpe, Jr.
}

(From the Department of Medicine, Medical College of Virginia, Richmond, Va.)

Several studies $(1-4)$ have shown that thyrotoxic patients have increased cutaneous blood flow, presumably for increased heat dissipation. The mechanisms that increase skin blood flow in thyrotoxicosis are not known.

Although it is established that calf and forearm blood flows are increased in thyrotoxicosis $(4,5)$, it is not known to what extent increased skeletal muscle blood flow contributes to this augmentation in blood flow. Since skin blood flow in normal subjects constitutes a considerable portion of forearm blood flow (6) and since skin blood flow is further increased in thyrotoxicosis, the state of the circulation to skeletal muscle cannot be estimated with confidence from measurements of total forearm blood flow. Similar considerations apply to the use of total calf blood flow for this purpose (7).

The purposes of the present investigation are: 1) to identify the mechanisms responsible for the increased cutaneous blood flow in thyrotoxicosis, 2) to study the circulation of forearm skeletal muscle in thyrotoxic patients, and 3) to examine the relationship between the changes in the circulation to the limbs and the alterations of the systemic circulation as a whole in such patients.

\section{Methods}

Twenty-three patients with thyrotoxicosis ranging in age from 16 to 68 years (mean age, 36 years) were studied. The diagnosis was based on the clinical symptoms

* Submitted for publication July 23, 1964; accepted February 25, 1965.

Supported in part by grants H-3361, HTS-5573, and FR 000 16-02 from the National Institutes of Health.

$\dagger$ Address requests for reprints to Dr. Hermes A. Kontos, Cardiovascular Laboratory, Department of Medicine, Medical College of Virginia, Richmond 19, Va.

$\ddagger$ Occupant of Virginia Heart Association Chair of Cardiovascular Research.

§ Recipient of Research Career Award from the $\mathrm{Na}$ tional Heart Institute. and signs and was confirmed by the usual laboratory examinations (protein-bound iodine and radioactive iodine uptake by the thyroid gland). None of the patients had evidence of organic cardiovascular disease. Sixteen normal subjects ranging in age from 22 to 54 years (mean age, 34 years) were similarly studied and served as controls. Eleven of these subjects were medical or college student volunteers. The remaining five subjects were patients that had recovered from minor illnesses. All studies were performed in the postabsorptive state in an air-conditioned laboratory (room temperature, 23 to $24^{\circ}$ C) while the subjects lay recumbent on a table.

Cardiac output was determined by an indicator-dilution method. A known amount of indocyanine green was injected suddenly through a calibrated syringe into an antecubital vein and rapidly propelled into the central circulation with $10 \mathrm{ml}$ of isotonic saline solution. Dye concentration in arterial blood was measured continuously with a Gilford densitometer. Cardiac output was calculated from dye curves after replotting on semilogarithmic paper. Oxygen consumption rates were determined by the timed collection of expired air in Douglas bags for 5 minutes and subsequent determination of its composition by the Scholander micrometer gas analyzer (8). Arterial blood pressure was measured with a Statham P23-D strain-gauge. Mean pressure was obtained by electronic integration. Systemic vascular resistance was calculated as the ratio of mean arterial blood pressure divided by the cardiac index. Blood flows to the hand or to the forearm were measured by venous occlusion plethysmography using a plethysmograph filled with water whose temperature was maintained thermostatically at 32 to $33^{\circ} \mathrm{C}$. When forearm blood flow was measured, the circulation to the hand was arrested by inflating a wrist cuff to a pressure well above the patient's systolic blood pressure. Arterial blood was obtained from an 18-gauge Cournand needle placed into the brachial artery. Forearm venous blood was obtained from superficial and deep forearm veins by retrograde catheterization with polyethylene catheters whose tips lay in the portion of the forearm enclosed by the plethysmograph. Catheterization of deep forearm veins was carried out according to the method of Mottram (9). Between sampling of venous blood these catheters were kept patent by the slow infusion of isotonic saline solution. It is known that superficial forearm veins contain blood coming from the superficial tissues of the forearm, whereas deep forearm veins contain blood coming primarily from skeletal 
TABLE I

Hand and forearm blood flows and arteriovenous oxygen differences in the forearm in thyrotoxicosis*

\begin{tabular}{|c|c|c|c|}
\hline & Thyrotoxic patients & Control subjects & p \\
\hline $\begin{array}{l}\text { Hand blood flow, } \\
\mathrm{ml} / \mathrm{min} / 100 \mathrm{ml}\end{array}$ & $17.8 \pm 1.5$ & $5.5 \pm 0.8$ & $<0.001$ \\
\hline $\begin{array}{l}\text { Forearm blood flow, } \\
\mathrm{ml} / \mathrm{min} / 100 \mathrm{ml}\end{array}$ & $9.3 \pm 0.7$ & $2.9 \pm 0.3$ & $<0.001$ \\
\hline $\begin{array}{l}\text { Arterial blood oxygen content, } \\
\quad m l / 100 \mathrm{ml}\end{array}$ & $15.83 \pm 0.44(23)$ & $17.30 \pm 1.35(11)$ & NS \\
\hline $\begin{array}{l}\text { Arterial-deep forearm } \\
\text { venous oxygen difference, } \\
m l / 100 \mathrm{ml}\end{array}$ & $5.67 \pm 0.53$ & $7.99 \pm 0.35(9)$ & $<0.01$ \\
\hline $\begin{array}{l}\text { Arterial-superficial forearm } \\
\text { venous oxygen difference, } \\
m l / 100 \mathrm{ml}\end{array}$ & $2.17 \pm 0.19(8)$ & $3.92 \pm 0.19(5)$ & $<0.001$ \\
\hline
\end{tabular}

* All values are mean \pm standard error. Numbers in parentheses represent the number of patients or subjects from which each mean value was derived.

muscle (10). Since the inflation of a venous collecting cuff is known to alter, for a few seconds, the oxygen saturation of blood obtained from deep forearm veins (11), sampling from venous catheters was commenced at least 30 seconds following the last blood flow determination. The oxygen and carbon dioxide contents of blood samples were determined by the method of Van Slyke and Neill (12).

The contribution of skin and skeletal muscle blood flow to the total forearm blood flow was determined by measuring forearm blood flow before and after the circulation to the skin was completely suppressed by epinephrine iontophoresis. Epinephrine iontophoresis was carried out by the method of Cooper, Edholm, and Mottram (6) using a current maintained at $20 \mathrm{ma}$ for at least 20 minutes. Upon completion of iontophoresis the forearm was immediately replaced in the plethysmograph, and blood flow determinations were resumed immediately. Experiments in which any evidence of significant absorption of epinephrine into the circulation occurred were not included in the results. A rise in blood pressure, tachycardia, and a postiontophoresis blood flow greater than the preiontophoresis value were taken as criteria for such absorption (6). In successful experiments the skin of the forearm was uniformly blanched and remained so until the completion of the experiment. Also in such experiments the blood flow remained constant throughout the period of observation. Abatement of iontophoresis during the experiment was denoted by a continuously rising blood flow. Such experiments were rejected. Observations were not extended beyond the forty-fifth minute after the end of iontophoresis. Since after suppression of cutaneous forearm blood flow by this method, the residual blood flow represents almost exclusively blood flow to skeletal muscle (6), it was possible to calculate the oxygen consumption and carbon dioxide production of forearm skeletal muscle from determinations of blood flow following epinephrine iontophoresis and the difference of oxygen and carbon dioxide concentrations in arterial and deep forearm venous blood. In each instance two to three sets of arteriovenous differences were obtained. The results reported are based on experiments in which the conditions for application of the Fick principle, e.g., constant blood flow and constant arterial and venous concentrations of metabolites, were fulfilled (13). The calculation of oxygen consumption and carbon dioxide production of forearm skeletal muscle described above assumes that the concentration of these substances in the venous blood sampled is representative of all skeletal muscle enclosed in the plethysmograph (13). Since it was not possible to catheterize more than one deep vein in any given forearm, this assumption lacks experimental verification.

The effect of intra-arterial atropine administration on forearm or hand blood flows was studied in 12 thyrotoxic patients and in 5 normal subjects. After control measurements of forearm blood flow or hand blood flow were made, atropine was administered into the brachial artery at a rate of $0.2 \mathrm{mg}$ per minute for a period of 5 minutes. The completeness of atropinization was verified by the absence of a vasodilator response to the intraarterial injection of acetylcholine given in $1 \mathrm{ml}$ of isotonic saline.

TABLE II

Distribution of forearm blood flow between skin and skeletal muscle in thyrotoxicosis

\begin{tabular}{cccc}
\hline Name & $\begin{array}{c}\text { Forearm } \\
\text { blood } \\
\text { flow }\end{array}$ & $\begin{array}{c}\text { Skin } \\
\text { blood } \\
\text { flow }\end{array}$ & $\begin{array}{c}\text { Skeletal } \\
\text { muscle } \\
\text { blood } \\
\text { flow }\end{array}$ \\
CBa & \multicolumn{3}{c}{ ml/min/100 ml forearm } \\
AL & 6.4 & 3.5 & 2.9 \\
BD & 6.3 & 3.5 & 2.8 \\
LTu & 9.1 & 3.8 & 5.3 \\
RS & 8.3 & 3.8 & 4.5 \\
MS & 7.3 & 2.5 & 4.8 \\
SC & 10.2 & 2.4 & 7.8 \\
Mean & 9.5 & 4.8 & 4.7 \\
SE & 8.2 & 3.5 & 4.7 \\
Mean control & 0.6 & 0.3 & 0.6 \\
SE & 2.4 & 1.1 & 1.3 \\
p & 0.3 & 0.2 & 0.1 \\
& $<0.001$ & $<0.001$ & $<0.001$ \\
\hline
\end{tabular}


TABLE III

Oxygen consumption and carbon dioxide production of forearm skeletal muscle in thyrotoxicosis*

\begin{tabular}{|c|c|c|c|c|c|c|c|}
\hline Name & MBF & $a_{O_{2}}$ & a-vdd $\mathrm{O}_{2}$ & $\mathrm{a}_{\mathrm{CO}_{2}}$ & a-vdd $\mathrm{CO}_{2}$ & $\mathrm{v}_{\mathrm{O}_{2}}$ & $\mathrm{~V}_{\mathrm{CO}_{2}}$ \\
\hline & $\underset{\mathrm{ml} / \mathrm{min} /}{100 \mathrm{ml}}$ & $\mathrm{ml} / 100 \mathrm{ml}$ & $\mathrm{ml} / 100 \mathrm{ml}$ & $\mathrm{ml} / 100 \mathrm{ml}$ & $\mathrm{ml} / 100 \mathrm{ml}$ & $\underset{\mathrm{ml} / \mathrm{min} /}{100 \mathrm{ml}}$ & $\begin{array}{l}\mathrm{ml} / \mathrm{min} / \\
100 \mathrm{ml}\end{array}$ \\
\hline $\begin{array}{l}\text { CBa } \\
\text { AL } \\
\text { BD } \\
\text { LTu } \\
\text { RS } \\
\text { MS } \\
\text { SC }\end{array}$ & $\begin{array}{l}2.9 \\
2.8 \\
5.3 \\
4.5 \\
4.8 \\
7.8 \\
4.7\end{array}$ & $\begin{array}{l}15.34 \\
14.30 \\
14.40 \\
14.89 \\
16.46 \\
15.30 \\
18.80\end{array}$ & $\begin{array}{l}6.92 \\
6.09 \\
4.07 \\
6.46 \\
5.86 \\
3.80 \\
4.72\end{array}$ & $\begin{array}{l}50.74 \\
52.77 \\
47.80 \\
51.63 \\
35.72 \\
43.00 \\
55.90\end{array}$ & $\begin{array}{l}4.81 \\
4.09 \\
4.58 \\
4.67 \\
3.34 \\
3.35 \\
2.00\end{array}$ & $\begin{array}{l}0.201 \\
0.171 \\
0.216 \\
0.291 \\
0.281 \\
0.296 \\
0.222\end{array}$ & $\begin{array}{l}0.139 \\
0.115 \\
0.243 \\
0.210 \\
0.160 \\
0.261 \\
0.094\end{array}$ \\
\hline $\begin{array}{c}\text { Mean } \\
\text { SE }\end{array}$ & $\begin{array}{l}4.7 \\
0.6\end{array}$ & $\begin{array}{r}15.64 \\
0.59\end{array}$ & $\begin{array}{l}5.42 \\
0.46\end{array}$ & $\begin{array}{r}48.22 \\
2.59\end{array}$ & $\begin{array}{l}3.83 \\
0.38\end{array}$ & $\begin{array}{l}0.240 \\
0.019\end{array}$ & $\begin{array}{l}0.175 \\
0.024\end{array}$ \\
\hline $\begin{array}{l}\text { Mean control } \\
\text { SE } \\
\mathrm{p}\end{array}$ & $\begin{array}{c}1.3 \\
0.1 \\
<0.001\end{array}$ & $\begin{array}{c}19.17 \\
0.37 \\
<0.001\end{array}$ & $\begin{array}{c}9.84 \\
0.62 \\
<0.001\end{array}$ & $\begin{array}{c}46.63 \\
1.62 \\
\text { NS }\end{array}$ & $\begin{array}{r}6.38 \\
0.64 \\
<0.01\end{array}$ & $\begin{array}{r}0.130 \\
0.008 \\
<0.001\end{array}$ & $\begin{array}{r}0.083 \\
0.007 \\
<0.01\end{array}$ \\
\hline
\end{tabular}

${ }^{*} \mathrm{MBF}=$ skeletal muscle blood flow; $\mathrm{a}_{\mathrm{O}_{2}}$ and $\mathrm{acO}_{2}=$ arterial blood oxygen and carbon dioxide concentrations respectively; a-vd $\mathrm{O}_{2}$ and a-vd $\mathrm{CO}_{2}=$ arterial-deep forearm venous oxygen and carbon dioxide differences respectively; $\mathrm{V}_{\mathrm{O}_{2}}$ and $\mathrm{V}_{\mathrm{CO}_{2}}=$ oxygen consumption and carbon dioxide production respectively.

Experimental procedure. After completion of arterial and venous punctures a rest period of 30 to 45 minutes was allowed. Observations were made in the following order : hand blood flow, oxygen consumption and cardiac output, forearm blood flow, effect of atropine on limb blood flow. In experiments in which the effect of atropine on hand blood flow was studied, the order was changed and hand blood flow was measured last. In experiments in which epinephrine iontophoresis was done, measurement of oxygen consumption, cardiac output, and in some cases hand blood flow was omitted.

Statistical analysis of the results was done with a $t$ test (14).

\section{Results}

Hand blood flow, forearm blood flow, and arteriovenous oxygen differences in the forearm. Thyrotoxic patients had significantly increased hand and forearm blood flows (Table I). In both areas the average blood flow was $320 \%$ of the corresponding mean value for the control subjects. The mean arterial-deep forearm venous and mean arterial-superficial forearm venous oxygen differences were significantly lower than the corresponding values for control subjects (Table I).

Distribution of total forearm blood flow between skin and skeletal muscle. Epinephrine iontophoresis of the forearm was carried out successfully in seven thyrotoxic patients and in five control subjects. Skin forearm blood flow (difference between forearm blood flow before and after epinephrine iontophoresis) was increased in all seven thyrotoxic patients averaging $318 \%$ of the mean value for control subjects (Table II). Forearm skeletal muscle blood flow (forearm blood flow after epinephrine iontophoresis) was also increased in all patients studied, averaging $361 \%$ of the mean value for control subjects (Table II).

Metabolism of forearm skeletal muscle. The oxygen consumption and carbon dioxide production of forearm skeletal muscle were determined in seven thyrotoxic patients and five control subjects following epinephrine iontophoresis of the forearm. The mean arterial deep forearm venous oxygen and carbon dioxide differences were significantly reduced in thyrotoxic patients (Table

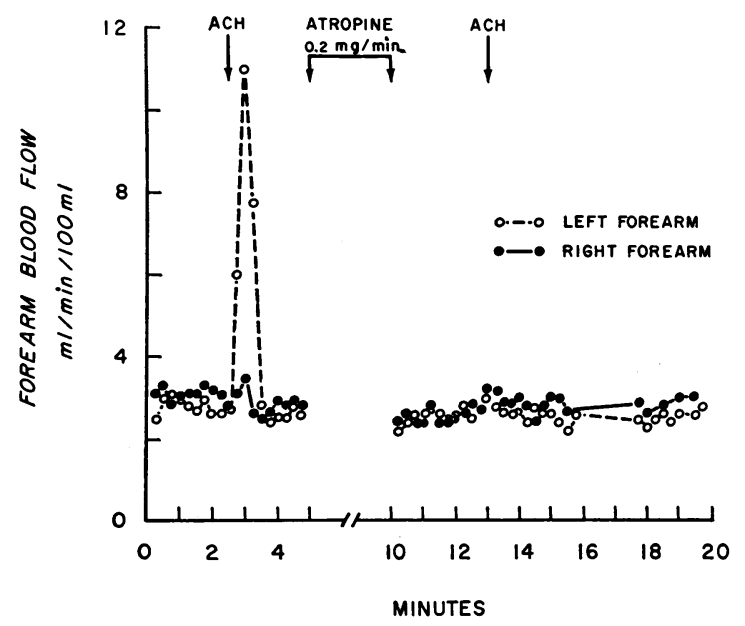

Fig. 1. EFFEct of INFUSion of ATROPINe into the LEFT BRACHIAL ARTERY ON FOREARM BLOOD FLOW OF A NORMAL SUBJECT. At the arrows marked $\mathrm{ACH}, 20 \mu \mathrm{g}$ of acetylcholine was injected into the left brachial artery. 


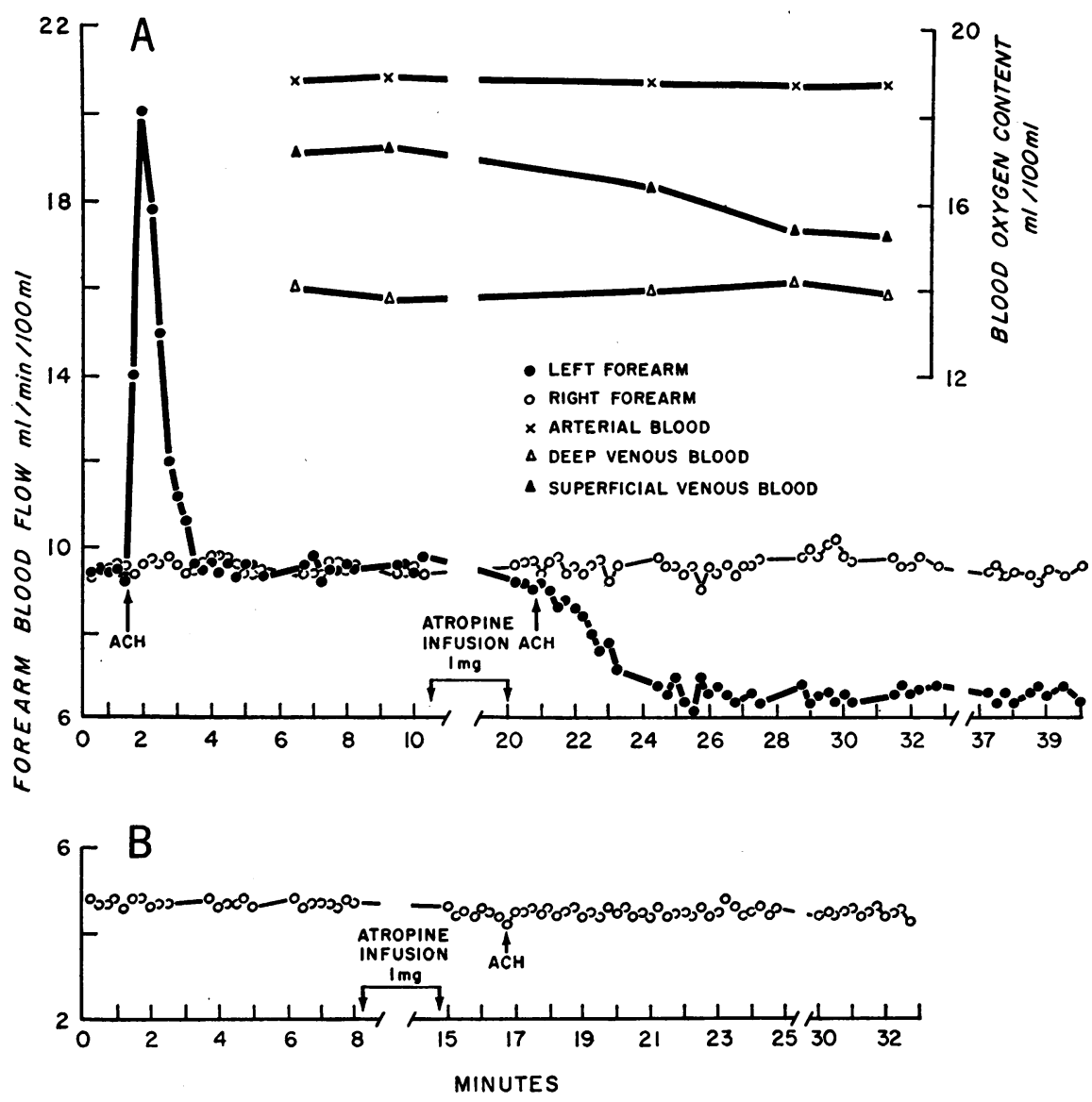

Fig. 2. EFFect of INTRA-ARTERIAL INFUSION OF ATROPINE ON FOREARM BLOOD FLOW IN A THYRotoxic PATIENT (SC). A : Atropine was administered into the left brachial artery. Both forearms intact. B: Atropine was infused into the right brachial artery following epinephrine iontophoresis of the right forearm. At the arrows marked $\mathrm{ACH}$, $20 \mu \mathrm{g}$ of acetylcholine was injected into the left brachial artery in A and into the right brachial artery in B. Open circles : right forearm blood flow; solid circles : left forearm blood flow; $X=$ arterial blood oxygen content; open triangles: deep forearm venous blood oxygen content; solid triangles: superficial forearm venous blood oxygen content.

III). Oxygen consumption and carbon dioxide production rates of forearm skeletal muscle were increased in all seven thyrotoxic patients (Table III). The mean oxygen consumption and mean carbon dioxide production rates of forearm skeletal muscle in thyrotoxic patients were $184 \%$ and $210 \%$ of the corresponding values for the control subjects.

Effect of intra-arterial atropine on hand and forearm blood flows. After the administration of atropine no tachycardia or change in the size of the pupils was observed, indicating that the drug did not enter the systemic circulation in significant amounts. The effect of atropine on forearm blood flow was studied in three normal subjects. Forearm blood flow did not change in two subjects (Figure 1), but increased slightly in one. The increase in forearm blood flow in this subject was accompanied by decrease in the arterialdeep forearm venous oxygen difference, suggesting that the hyperemia was due to increased blood flow to skeletal muscle. The administration of atropine resulted in a significant decrease in forearm blood flow in each of seven thyrotoxic patients studied (Table IV and Figure 2). In four patients the decrease in blood flow was present upon completion of the infusion of atropine. In the remaining three patients blood flow decreased 
TABLE IV

Effect of intra-arterial atropine on forearm blood flow and arteriovenous oxygen differences in the forearm in thyrotoxicosis*

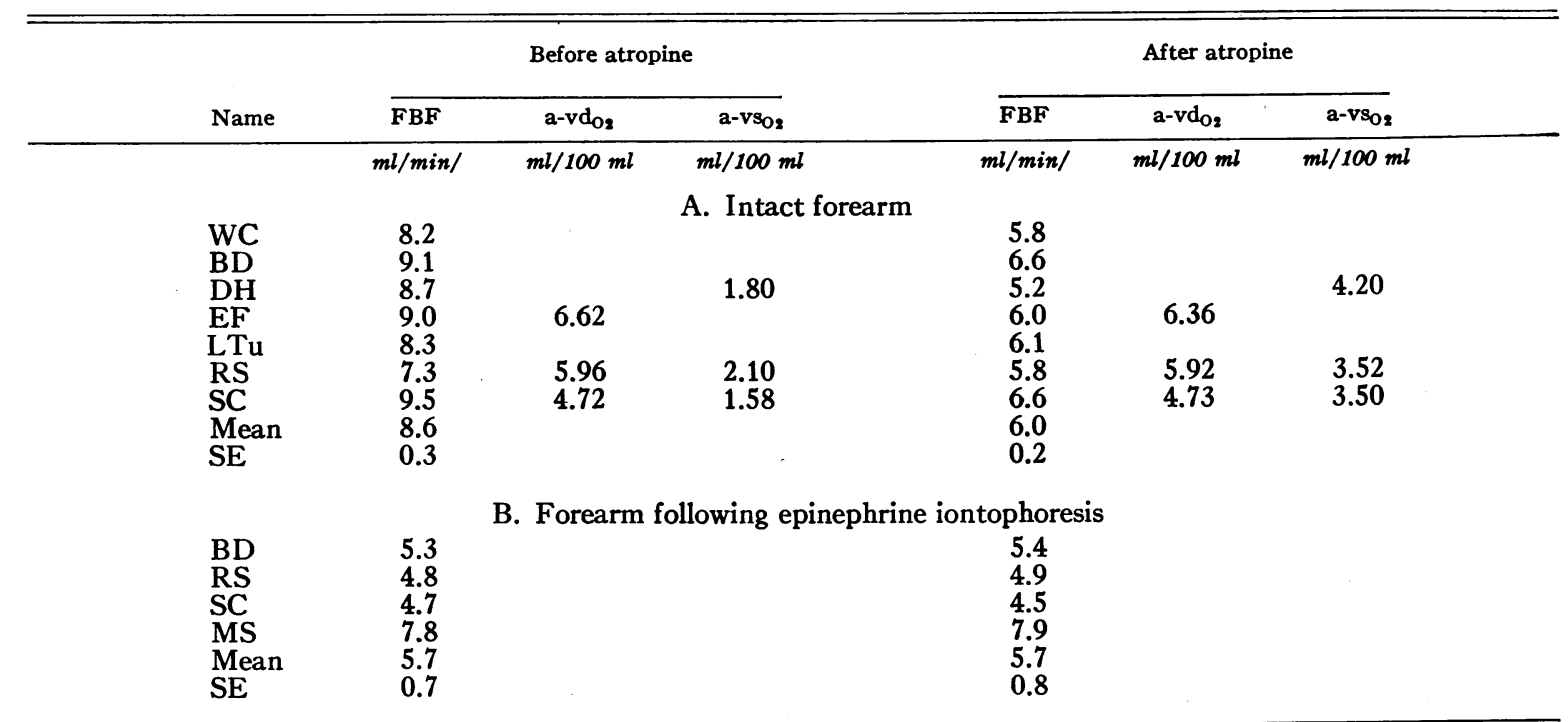

${ }^{*} \mathrm{FBF}=$ forearm blood flow $; \mathrm{a}^{\mathrm{vd} \mathrm{O}_{2}}=$ arterial-deep forearm forearm venous oxygen difference.

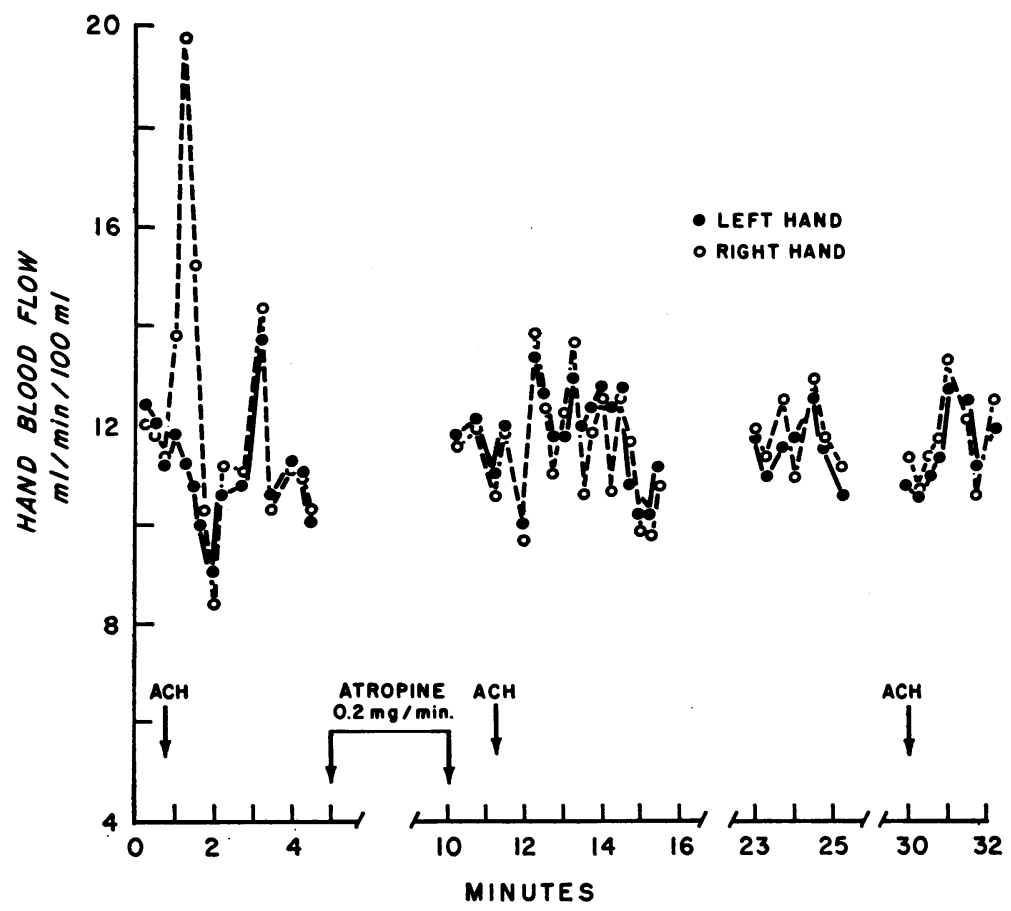

Fig. 3. EFFECT OF INFUSION OF ATROPINE INTO THE RIGHT BRACHIAL ARTERY ON HAND BLOOD FLOW OF A THYROTOXIC PATIENT (AL). At the arrows marked $\mathrm{ACH}, 200 \mu \mathrm{g}$ of acetylcholine was injected into the right brachial artery. 


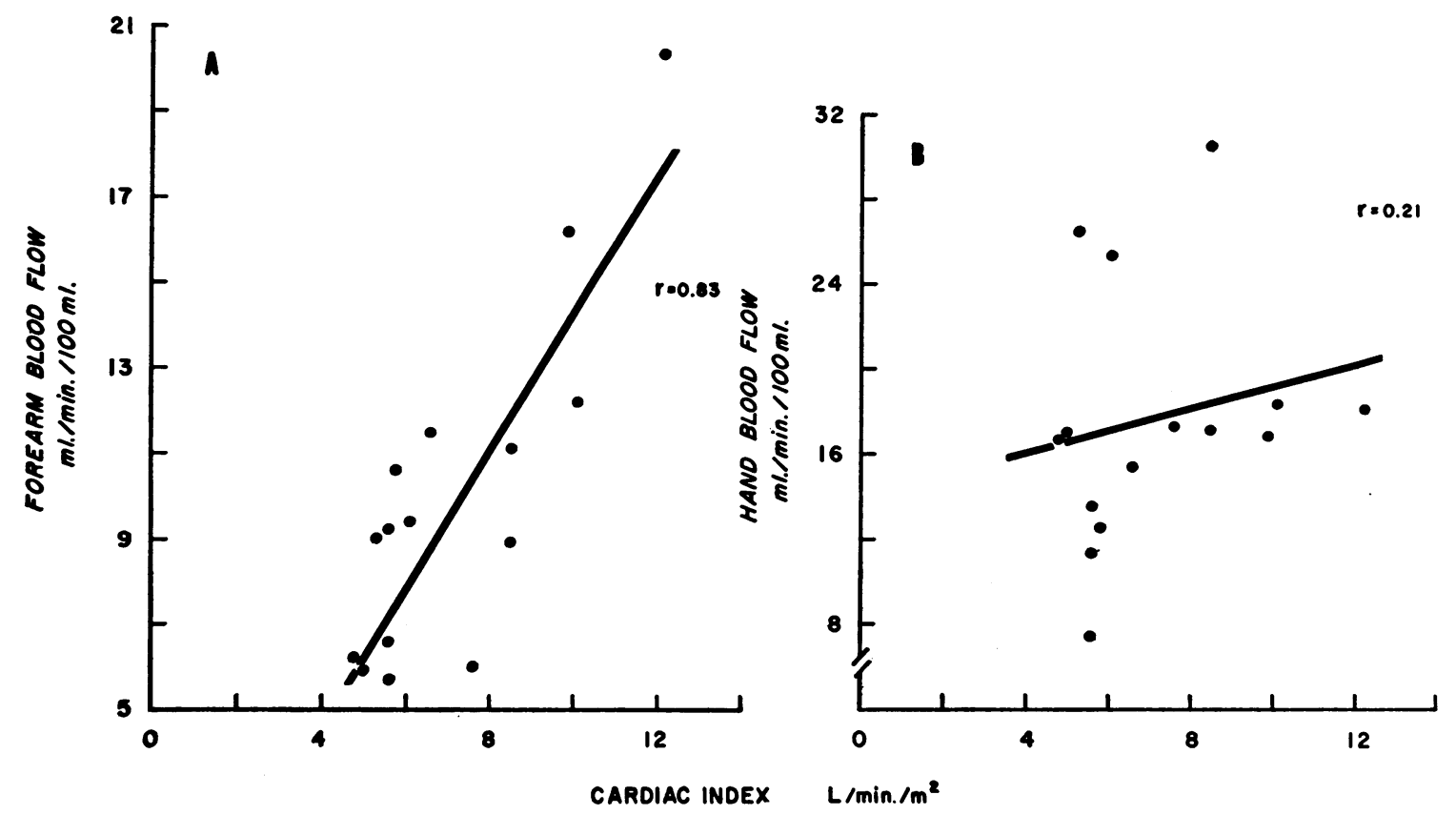

Fig. 4. A: Relationship of Forearm blood FLow to CARDiAC index in thyrotoxicosis. B: Relationship of HAND BLOOD FLOW TO CARDIAC INDEX IN THYROTOXICOSIS.

over a period of 1 to 3 minutes following the end of atropine infusion. This delay was not due to incomplete atropinization since in these patients the effect of acetylcholine was completely blocked (Figure 2). This decrease in blood flow was accompanied by increase in arterial-superficial fore-

TABLE V

Systemic circulatory alterations in thyrotoxicosis*

\begin{tabular}{|c|c|c|c|c|c|}
\hline & \multicolumn{2}{|c|}{$\begin{array}{l}\text { Thyrotoxic } \\
\text { patients }\end{array}$} & \multicolumn{2}{|c|}{$\begin{array}{l}\text { Control } \\
\text { subjects }\end{array}$} & \multirow[t]{2}{*}{ p } \\
\hline $\begin{array}{l}\text { Body surface area, } \\
m^{2}\end{array}$ & 1.59 & \pm 0.04 & 1.86 & \pm 0.06 & \\
\hline $\begin{array}{l}\text { Cardiac index, } \\
\mathrm{L} / \mathrm{min} / \mathrm{m}^{2}\end{array}$ & 7.1 & \pm 0.6 & 3.3 & \pm 0.1 & $<0.001$ \\
\hline $\begin{array}{l}\text { Heart rate, } \\
\text { beats } / \text { min }\end{array}$ & 109 & \pm 4.8 & 67 & \pm 4.6 & $<0.001$ \\
\hline $\begin{array}{l}\text { Stroke volume index, } \\
\mathrm{ml} / \mathrm{beat} / \mathrm{m}^{2}\end{array}$ & 65.2 & \pm 3.8 & 49.1 & \pm 2.1 & $<0.01$ \\
\hline $\begin{array}{l}\text { Mean arterial blood } \\
\text { pressure, } \\
m m ~ H g\end{array}$ & 109 & \pm 3.7 & 100 & \pm 3.6 & NS \\
\hline $\begin{array}{l}\text { Systemic vascular } \\
\text { resistance, } \\
\text { mm } \mathrm{Hg} / \mathrm{L} / \mathrm{min} / \mathrm{m}^{2}\end{array}$ & 16.6 & \pm 1.4 & 31.4 & \pm 2.2 & $<0.001$ \\
\hline $\begin{array}{r}\text { Oxygen consumption, } \\
m l(S T P D) / \mathrm{min} / \mathrm{m}^{2}\end{array}$ & 194 & \pm 9.2 & 125 & \pm 6.2 & $<0.001$ \\
\hline $\begin{array}{l}\text { Ratio oxygen consumption } \\
\text { cardiac index }\end{array}$ & 29.1 & \pm 2.2 & 39.0 & \pm 2.6 & $<0.01$ \\
\hline
\end{tabular}

* These data were obtained from 15 thyrotoxic patients and 11 control subjects. All values are mean \pm standard error. STPD $=$ standard temperature, pressure, dry. arm venous oxygen difference, but no change in arterial-deep forearm venous oxygen difference (Figure 2 and Table IV). In four thyrotoxic patients the administration of atropine into the brachial artery after forearm skin blood flow was completely suppressed by epinephrine iontophoresis had no effect on blood flow (Figure 2 and Table IV). In three of these patients the administration of atropine into the brachial artery of the opposite limb had resulted in significant decrease in blood flow to the intact forearm. These findings indicate that the decrease in forearm blood flow following the administration of atropine in thyrotoxic patients was due to decreased skin blood flow. In two normal subjects and in four thyrotoxic patients, the administration of atropine had no effect on hand blood flow (Figure 3 ).

General circulatory alterations. Thyrotoxic patients had significantly increased cardiac index, heart rate, stroke volume index, and oxygen consumption rate, and significantly decreased systemic vascular resistance (Table V). The cardiac output in thyrotoxic patients was increased out of proportion to the increased oxygen consumption rate, as indicated by the significantly reduced ratio of oxygen consumption to cardiac index (Ta- 
ble V). In thyrotoxic patients the cardiac index correlated well with forearm blood flow $(r=$ $0.83)$ but poorly with hand blood flow $(r=0.21)$ (Figure 4).

\section{Discussion}

Skin blood flow. It is generally accepted that skin blood flow is increased in thyrotoxicosis (15, 16). This view is based on measurements of hand blood flow (1-3) and on indirect estimates of total body skin blood flow obtained from multiple skin temperature measurements (4). The present study confirms the increased hand blood flow in thyrotoxic patients, and in addition it shows that skin blood flow is also increased in the forearm. In our patients the percentile increase in hand blood flow and forearm skin blood flow was approximately the same, averaging 3.23 and 3.18 times the corresponding values for control subjects, respectively. These figures agree closely with the conclusion of Stewart and Evans, who estimated that total skin blood flow in thyrotoxicosis was increased three to four times (4).

The considerable decrease in forearm skin blood flow following the intra-arterial administration of atropine indicates that the increase in blood flow to the skin of this part of the body in thyrotoxicosis is to a major extent mediated by a cholinergic mechanism. In contrast, the absence of change in hand blood flow following the administration of atropine suggests that a cholinergic mechanism does not play a significant role in the increased hand blood flow in thyrotoxicosis. The existence of cholinergic vasodilator fibers to the skin of the human forearm is well established (17). Activation of these fibers is primarily responsible for the increase in forearm skin blood flow that occurs in normal subjects during body heating (17). In contrast, the increase in blood flow to the skin of the hand in response to body heating is due to decrease in sympathetic vasoconstrictor tone, without significant contribution from vasodilator nerve fibers (17-20). Thus, the mechanisms mediating the increase in skin blood flow in thyrotoxicosis resemble closely the mechanisms responsible for the increase in skin blood flow in normal subjects during body heating. This is not unexpected, since the purpose of skin vasodilatation in thyrotoxicosis is increased heat dissipation. Fox and Hilton (21) perfused the subcutaneous tissue of the human forearm with isotonic saline and found that during body heating the concentration of bradykinin in the perfusate increased. They suggested that the local formation of bradykinin resulting from sweat gland activity was responsible for the cutaneous vasodilatation occurring under these circumstances. Whether a similar mechanism plays a role in the production of increased forearm skin blood flow in thyrotoxicosis is not known.

Skeletal muscle blood flow. Previous investigations have shown that forearm and calf blood flow in thyrotoxic patients is considerably increased $(4,5)$. As noted before, in the presence of increased skin blood flow the state of the circulation to skeletal muscle in these areas cannot be reliably judged from measurements of total forearm or calf blood flow. That forearm skeletal muscle blood flow is increased in thyrotoxicosis was suggested by the finding of reduced arterialdeep forearm venous oxygen difference, and it was confirmed by direct measurement following suppression of forearm skin blood flow by epinephrine iontophoresis. If we assume that a similar increase in blood flow occurred in other muscles of the body, the increase in skeletal muscle blood flow is more important quantitatively than the increase in cutaneous blood flow, for skeletal muscle constitutes about $40 \%$ of body weight. The precise mechanisms by which skeletal muscle blood flow is increased have not been identified. As shown herein, however, oxygen consumption and carbon dioxide production of forearm skeletal muscle are increased. Thus, skeletal muscle partakes in the increased metabolism that occurs in most tissues of the body in thyrotoxicosis. The augmented blood flow is very likely related to the increased metabolic rate but the mechanism of this relationship is not known. In spite of the increase in oxygen consumption rate of forearm skeletal muscle, the arteriovenous oxygen difference across it was reduced. Thus skeletal muscle met its increased oxygen requirements by means of increased blood flow rather than by increased oxygen extraction. In fact, the increase in blood flow was greater than that needed to fulfill the increase in oxygen requirements. This suggests the possibility that the augmented blood flow is not directly related to the increased oxygen needs. An alterna- 
tive possibility is that part of the increased blood flow is passing through vessels that exchange poorly with tissues. Evidence obtained from animal experiments (22-25) supports the existence of two types of circulation in skeletal muscle, one type subserving the nutritional requirements of the tissues and the other exchanging poorly with tissue and probably consisting of vessels that pass through connective tissue septa and tendon (25).

The arterial oxygen content for the entire group of thyrotoxic patients was not significantly different from the corresponding value for the control subjects (Table I). Some of our patients were, however, mildly anemic. As a result of this the group of patients in whom epinephrine iontophoresis was performed had a significantly lower arterial oxygen content than the corresponding group of control subjects (Table III). Verel and Duff (26) studied forearm blood flow and forearm deep venous oxygen content in 12 patients with anemia. They found that forearm blood flow was normal until hemoglobin concentration decreased below $4 \mathrm{~g}$ per $\mathrm{ml}$ blood or venous oxygen saturation decreased below $15 \%$. It is therefore unlikely that the mild anemia seen in our patients had a significant effect on forearm blood flow.

Our findings suggest that cholinergic vasodilator fibers are not involved in the increase in forearm skeletal muscle blood flow in thyrotoxicosis. This is based on the absence of a change in arterial-deep forearm venous blood oxygen difference following the administration of atropine and on the lack of change in blood flow in the four patients in whom atropine was given following epinephrine iontophoresis.

General circulatory alterations. It is generally accepted that in thyrotoxicosis cardiac output is elevated, heart rate is increased, and systemic vascular resistance is reduced. Disagreement exists in regard to stroke volume and arteriovenous oxygen difference across the systemic circulation.

In our patients the increase in cardiac ouput was brought about by increases in both heart rate and stroke volume. This agrees with the findings of Bishop, Donald, and Wade (27) and of Graettinger, Muenster, Selverstone, and Campbell (28). In contrast, in the patients studied by Myers, Brannon, and Holland (29), by Humerfelt, Müller, and Storstein (30), and by Anthonisen, Holst, and Thomsen (31), stroke volume was normal, the increased cardiac output being dependent entirely on increased heart rate. In the present study the arterial-mixed venous oxygen difference, calculated from cardiac output and oxygen consumption rates, was significantly reduced. This agrees with the findings of Bishop and his colleagues (27) and Graettinger and associates (28), but contrasts with the results of Myers and co-workers (29), Humerfelt and coworkers (30), and Anthonisen and co-workers (31), who found a normal arterial-mixed venous oxygen difference. In our patients the diminished arterial-mixed venous oxygen difference was probably related to the diminished arteriovenous oxygen difference across skin and skeletal muscle.

\section{Summary}

1. Circulatory studies were performed in 23 thyrotoxic patients and in 16 normal subjects who served as controls.

2. Hand and forearm blood flows in thyrotoxic patients averaged $320 \%$ of the corresponding mean values for control subjects. Arterial-deep forearm venous and arterial-superficial forearm venous oxygen differences were significantly reduced in thyrotoxicosis.

3. The distribution of forearm blood flow between skin and skeletal muscle was determined in seven thyrotoxic patients and five control subjects by completely suppressing the circulation to the skin by epinephrine iontophoresis. Forearm skin blood flow and forearm skeletal muscle blood flow were significantly increased in thyrotoxic patients, averaging $318 \%$ and $361 \%$ of the corresponding mean values for control subjects.

4. In the patients and control subjects in whom epinephrine iontophoresis of the forearm was carried out, the oxygen consumption and carbon dioxide production rates of forearm skeletal muscle were determined by application of the Fick principle. In thyrotoxic patients the oxygen consumption and carbon dioxide production rates of forearm skeletal muscle were increased, averaging $184 \%$ and $210 \%$ of the corresponding values for control subjects.

5. Administration of atropine into the brachial artery had no effect on forearm or hand blood flows in normal subjects or on hand blood flow in thyrotoxic patients, but resulted in significant de- 
crease in forearm blood flow in seven thyrotoxic patients. Atropine had no effect on forearm blood flow of four patients in whom the circulation to forearm skin was suppressed by epinephrine iontophoresis, indicating that the observed decrease in blood flow following atropine infusion in the intact forearm was due to decrease in skin blood flow. These findings suggest that the increase in forearm skin blood flow in thyrotoxicosis is mediated by a cholinergic mechanism and that a cholinergic mechanism does not play a significant role in the production of increased hand blood flow in thyrotoxicosis.

6. In 15 thyrotoxic patients cardiac index, heart rate, stroke volume, and oxygen consumption rates were increased, whereas systemic vascular resistance and calculated arterial-mixed venous blood oxygen difference were diminished. There was a good correlation between cardiac index and forearm blood flow but a poor correlation between cardiac index and hand blood flow.

\section{References}

1. Hewlett, A. W., and J. G. Van Zwaluwenburg. The rate of blood flow in the arm. Heart 1909, 1, 87.

2. Stewart, G. N. Studies on the circulation in man. Harvey Lect. 1912-13, 113.

3. Abramson, D. I., and S. M. Fierst. Resting peripheral blood flow in the hyperthyroid state. Arch. intern. Med. 1942, 69, 409.

4. Stewart, H. J., and W. F. Evans. The peripheral blood flow in hyperthyroidism. Amer. Heart J. 1940, 20, 715.

5. Eichna, L. W., and R. W. Wilkins. Blood flow to the forearm and calf. IV. Thyroid-activity; observations on the relation of blood flow to metabolic rate. Bull. Johns Hopk. Hosp. 1941, 68, 512.

6. Cooper, K. E., O. G. Edholm, and R. F. Mottram. The blood flow in skin and muscle of the human forearm. J. Physiol. (Lond.) 1955, 128, 258.

7. Shepherd, J. T. Physiology of the Circulation in Human Limbs in Health and Disease. Philadelphia, W. B. Saunders, 1963, p. 3.

8. Scholander, P. F. Analyzer for accurate estimation of respiratory gases in one-half cubic centimeter samples. J. biol. Chem. 1947, 167, 235.

9. Mottram, R. F. The oxygen consumption of human skeletal muscle in vivo. J. Physiol. (Lond.) 1955, 128, 268.

10. Coles, D. R., K. E. Cooper, R. F. Mottram, and J. V. Occleshaw. The source of blood samples withdrawn from deep forearm veins via catheters passed upstream from the median cubital vein. J. Physiol. (Lond.) 1958, 142, 323.
11. Moreira, M. F., R. F. Mottram, and A. Y. Werner. The effect of venous pressure on the oxygen content of venous blood in the deep forearm veins. J. Physiol. (Lond.) 1956, 133, 255.

12. Van Slyke, D. D., and J. M. Neill. The determination of gases in blood and other solutions by vacuum extraction and manometric measurement. I. J. biol. Chem. 1924, 61, 523.

13. Zierler, K. L. Theory of the use of arteriovenous concentration differences for measuring metabolism in steady and non-steady states. J. clin. Invest. 1961, 40, 2111.

14. Snedecor, G. W. Statistical Methods, 5th ed. Ames, Iowa, Iowa State College Press, 1956, p. 45.

15. Shepherd, J. T. Physiology of the Circulation in Human Limbs in Health and Disease. Philadelphia, W. B. Saunders, 1963, p. 366.

16. Wade, O. L., and J. M. Bishop. Cardiac Output and Regional Blood Flow. Oxford, Blackwell, 1962, p. 207.

17. Roddie, I. C., J. T. Shepherd, and R. F. Whelan. The contribution of constrictor and dilator nerves to the skin vasodilatation during body heating. J. Physiol. (Lond.) 1957, 136, 489.

18. Sarnoff, S. J., and F. A. Sineone. Vasodilator fibers in the human skin. J. clin. Invest. 1947, 26, 453.

19. Arnott, W. M., and J. M. Macfie. Effect of ulnar nerve block on blood flow in the reflexly vasodilated digit. J. Physiol. (Lond.) 1948, 107, 233.

20. Gaskell, P. Are there sympathetic vasodilator nerves in the vessels of the hands? J. Physiol. (Lond.) 1956, 131, 647.

21. Fox, R. H., and S. M. Hilton. Bradykinin formation in human skin as a factor in heat vasodilatation. J. Physiol. (Lond.) 1958, 142, 219.

22. Barcroft, H., and A. H. Kitchin. Are there arteriovenous anastomoses in the human forearm? Symposium sur les interactions artério-veineuses. Angéiologie 1957, 9 (no. 2), 24.

23. Hyman, C. Physiological implications of a dual circulation in muscle. Symposium sur les interactions artério-veineuses. Angéiologie 1957, 9 (no. 2), 25.

24. Lambert, J. Réactions vasculaires provoquées dans le muscle strié au repos chez le chien par l'ischémie temporaire expérimentale. II. Variations des réponses en fonction de la pression artérielle en amont. Arch. int. Physiol. 1957, 65, 46.

25. Barlow, T. E., A. L. Haigh, and D. N. Walder. Evidence for two vascular pathways in skeletal muscle. Clin. Sci. 1961, 20, 367.

26. Verel, D., and R. S. Duff. Circulatory adjustments of voluntary muscle in anemia. J. app. Physiol. 1958, 14, 225.

27. Bishop, J. M., K. W. Donald, and O. L. Wade. Circulatory dynamics at rest and on exercise in the hyperkinetic states. Clin. Sci. 1955, 14, 329. 
28. Graettinger, J. S., J. J. Muenster, L. A. Selverstone, and J. A. Campbell. A correlation of clinical and hemodynamic studies in patients with hyperthyroidism with and without congestive heart failure. J. clin. Invest. 1959, 38, 1316.

29. Myers, J. D., E. S. Brannon, and B. C. Holland. A correlative study of the cardiac output and the hepatic circulation in hyperthyroidism. J. clin. Invest. 1950, 29, 1069.
30. Humerfelt, S., O. Müller, and O. Storstein. The circulation in hyperthyroidism. A cardiac catheterization study before and after treatment. Amer. Heart J. 1958, 56, 87.

31. Anthonisen, P., E. Holst, and A. A. C. Thomsen. Determination of cardiac output and other hemodynamic data in patients with hyper- and hypothyroidism using dye dilution technique. Scand. J. clin. Lab. Invest. 1960, 12, 472. 